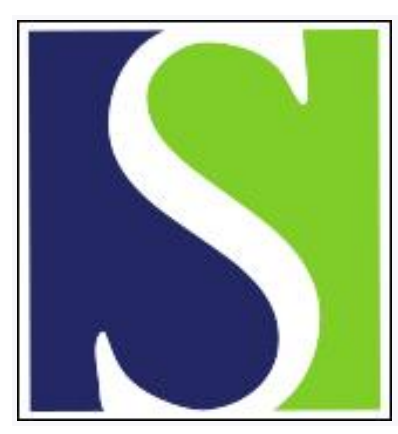

Scand J Work Environ Health 2000;26(1):52-61

https://doi.org/10.5271/sjweh.510

Issue date: Feb 2000

Past occupational exposure to asbestos among men in France

by Goldberg M, Banaei A, Goldberg S, Auvert B, Luce D, Guéguen A

Key terms: case-referent study; general population; reconstitution of exposure

This article in PubMed: www.ncbi.nlm.nih.gov/pubmed/10744178

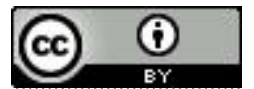




\title{
Past occupational exposure to asbestos among men in France
}

\author{
by Marcel Goldberg, MD, ${ }^{1}$ Alireza Banaei, MD, ${ }^{1}$ Stephen Goldberg, MSC, ${ }^{1}$ Bertran Auvert, MD, ${ }^{1}$ Danièle \\ Luce, PhD, ${ }^{1}$ Alice Guéguen, PhD'
}

\begin{abstract}
Goldberg M, Banaei A, Goldberg S, Auvert B, Luce D, Guéguen A. Past occupational exposure to asbestos among men in France. Scand J Work Environ Health 2000;26(1):52-61.

Objectives This study aimed at reconstructing changes in the frequency and levels of occupational asbestos exposure in France over the past century.

Methods Work histories were collected during 11 population-based case-referent studies recently carried out in France, and an asbestos-specific job-exposure matrix including 10625 jobs was used to estimate indices of past occupational asbestos exposure. The results were estimated from a sample of 4287 subjects, bootstrapped 200 times.

Results The distribution of socioeconomic categories within the sample was compared with that of the general population in 1954,1962,1968, 1975, and 1982. The proportion of blue-collar workers was similar. The highest proportion of exposed subjects was found between 1950 and 1980. Around 10\% of each 10-year age class was exposed to asbestos. For those born in 1930-1939, 15.2\% was exposed between the ages of 20 and 29 years. For each age class born in 1900-1939, the proportion exposed at least once by 60 years of age ranged from $18.2 \%$ to $24.5 \%$ and, of those exposed, the cumulative duration of exposure ranged from 11.3 to 15.4 years by the age of 60 years. A population exposure index showed that the heaviest exposure occurred between 1960 and 1970 and that the age classes born between 1920 and 1929 were the most heavily exposed. Time trends showed that the mean value of this index for the men aged 20-59 years reached a peak in the 1960s and then decreased.

Conclusions This study presents data of reasonable validity about occupational asbestos exposure in France and its trends over the past century; the data are being used to forecast the development of male mortality from mesothelioma in France.
\end{abstract}

Key terms case-referent studies, general population, reconstitution of exposure.

Asbestos is a known human carcinogen. Its related cancers are mesothelioma, in particular of the pleura, and lung cancer. Associations with other cancer sites (especially the larynx and colon) have been suggested, although they cannot be considered definitely established $(1,2)$. Asbestos also causes various noncancerous respiratory disorders (eg, asbestosis, pleural plaques) (3).

Asbestos-induced diseases are caused by the presence of naturally occurring exposure to asbestos in the environment, observed in some regions of the world, and probably by residence near asbestos manufacturing plants, which concerns only small local populations. However, occupational asbestos exposure is currently responsible for the vast majority of asbestos-induced diseases in the industrialized world (1-3).

Despite noticeable differences from one study to another, essentially because of the difference in exposure assessment methods and the different frequency of exposure in the populations studied, it is agreed that at least $80 \%$ of all mesotheliomas in industrialized nations are due to occupational asbestos exposure $(4,5)$, as are between $5 \%$ and $10 \%$ of all lung cancers (6).

The occupations most heavily exposed have changed over time. During the 1960 s, the incidence of mesothelioma increased primarily among workers in the asbestos mining and transformation industries, and among workers involved in the direct handling of asbestos (7). Since the 1980s, however, the incidence of asbestos-induced cancers has been highest in occupations involving work with asbestos-containing materials, construction and building workers in particular, but also for a diverse range of other jobs $(8,9)$.

Since the $1950 \mathrm{~s}$, a large and regular increase in mesothelioma incidence in the industrialized world has accompanied the massive development of asbestos use (10). Although many countries have taken steps to reduce the

1 INSERM Unité 88 (National Research Institute on Health and Medicine, Unit 88), Saint Maurice, France.

Reprint requests to: Dr Marcel Goldberg, INSERM Unité 88, Hôpital National de Saint-Maurice, 14, rue du Val d'Osne 94415 Saint-Maurice CEDEX, France. [E-mail: m.goldberg@st-maurice.inserm.fr] 
frequency and levels of asbestos exposure (11), predictions indicate that, for Western Europe, the trend toward increased mesothelioma mortality will continue for at least 2 decades, because of the 30-to-40-year latency pe$\operatorname{riod}(12)$.

It is thus important to know the distribution of occupational asbestos exposure in each country and how it has changed in recent decades. Accurate estimates of the population's exposure allows more realistic forecasts of changes in the incidence of asbestos-induced cancers than are possible with modeling based only on past mortality. This information can also facilitate the development and assessment of programs to monitor asbestos risk (11). Nonetheless, little has been published about asbestos exposure in general populations, and only partial data are available (13). In particular, case-referent studies about the relation of asbestos exposure and lung cancer or mesothelioma show extremely variable proportions of exposed referents, depending on the region studied (4); they do not allow an assessment of the prevalence of exposure among the general population.

The objective of this work was to describe the prevalence and levels of occupational asbestos exposure for the French male population and their changes over the century, according to the work histories of a representative sample of French men.

\section{Subjects and methods}

\section{Subjects}

We created a sample from several different populationbased case-referent studies, all of which included a complete work history obtained by a structured interview of the subject himself. Data were collected between 1984 and 1995. The subjects came from nearly all regions of France, from the most to the least industrialized. Their mean age at data collection was 59.2 years. The subjects included in this sample were the referents of all the studies. To increase the size of the sample, we also included cases, but only for studies involving disorders for which no connection with asbestos was known (bladder cancer, leukemia, and nephropathies), to avoid overestimation of exposure to asbestos. The data for each subject included a complete job history, with the starting and ending dates for each separate job or job episode, the occupation being coded according to the International Standard Classification of Occupations (ISCO) (14) and the industry according to the International Standard Industry Classification (ISIC) (15). The study was limited to men because of the paucity of complete work histories for women. We pooled data for 4700 subjects from 11 case-referent surveys (table 1).

\section{Assessment of asbestos exposure}

A job-exposure matrix (JEM) specific for asbestos and applicable to France was developed by Orlowski et al (26). Asbestos fiber types were not distinguished in the matrix. Its job axis combined ISCO and ISIC codes. This matrix provided the following information for each ISCO-ISIC combination: (i) an index of the probability of asbestos exposure (unexposed, $<0.1,0.1-0.5,0.5-$ $0.9,>0.9$ ), (ii) an index of the frequency of exposure $(<5 \%, 5-30 \%, 30-70 \%,>70 \%$ of work time), and (iii) an index of the intensity of exposure, expressed in fibers per milliliter $(\mathrm{f} / \mathrm{ml})(<0.1,0.1-1,1-10,>10 \mathrm{f} / \mathrm{ml})$. When significant technical or protective changes occurred that were likely to modify exposure conditions, the corresponding date was included in the matrix, and the exposure indices were modified. Thus the matrix could contain several periods for the same ISCO-ISIC combination. This job-exposure matrix included 10625 different ISCO-ISIC combinations, including those for different periods.

The work histories of the 4700 subjects included in our sample were linked with the job-exposure matrix. For 413 subjects, no job episode corresponded to a job coded in the matrix. These subjects have been excluded, and the analysis thus concerned a sample of 4287 men, with 12953 different job episodes.

Table 1. Main characteristics of the case-referent studies included in the sample.

\begin{tabular}{|c|c|c|c|c|}
\hline Author (reference) & Disease & $\begin{array}{l}\text { Number and type of } \\
\text { subjects included } \\
\text { in the sample }\end{array}$ & Period of interview & Region \\
\hline Boffetta et al, 1998 (16) & Lung cancer & 20 referents & $1988-1994$ & Mainly Paris area \\
\hline Clavel et al, 1995 (17) & Hairy cell leukemia & 649 cases and referents & $1990-1992$ & 18 different cities \\
\hline Cordier et al, 1993 (18) & Bladder cancer & 1375 cases and referents & $1984-1987$ & 6 different cities \\
\hline Hours et al, 1996 (19) & Myeloid acute leukemia & 255 cases and referents & $1991-1993$ & 7 different cities \\
\hline Hours et al, $1994(20)$ & Bladder cancer & 289 cases and referents & $1984-1987$ & Lyon area \\
\hline Hours et al, $1991(21)$ & Lung cancer & 459 referents & $1984-1990$ & Lyon area \\
\hline Iwatsubo et al, 1998 (9) & Pleural mesothelioma & 316 referents & $1987-1995$ & 5 different regions \\
\hline Luce et al, $1993(22)$ & Sinonasal cancer & 320 referents & $1986-1988$ & 10 different cities \\
\hline Richardson et al, 1992 (23) & Acute leukemia & 361 cases and referents & $1984-1988$ & Paris area \\
\hline Stengel et al, 1995 (24) & Glomerular nephropathies & 362 cases and referents & $1985-1990$ & Paris area \\
\hline Stucker et al, 1995 (25) & Lung cancer & 294 referents & $1990-1992$ & Paris and Besançon \\
\hline
\end{tabular}




\section{Sample validation}

We used French census data to verify the comparability of this sample with the French male population in terms of occupation. Age, gender, and occupational data were available from 5 different censuses, 1954, 1962, 1968, 1975 , and 1982. For each census and by age class (15$24,25-34,35-44,45-54$, and 55-64 years), we compared the proportion of subjects in the sample and in the French male population with a blue-collar job. The occupational classification for the census used the French code of socioprofessional categories (27) in effect at each census, while the sample was coded only according to the 1968 ISCO. Although the detailed codes of these classifications are not completely compatible, it was easy to classify the occupations of the French socioprofessional categories corresponding to those of the ISCO code that began with 7,8 , or 9 (production and related workers, transport equipment operators, and laborers). The comparison concerned only these categories, which included the vast majority of asbestos-exposed occupations: in the sample, among the 4539 job episodes that were considered exposed to asbestos by the job-exposure matrix, $3748(83 \%)$ fell into these ISCO categories. The comparison was carried out according to the defined age ciasses. Some of the censuses, however, used different definitions for the youngest age class (20-24 years in 1954 and 1982, 17-24 years in 1975), and we grouped the sample data in the same way as the census data for these years.

\section{Statistical analysis}

The variables we studied included the proportion of men occupationally exposed to asbestos and the duration of exposure. The exposure indices were calculated for specific periods and cumulatively. We also calculated a population exposure index (PEI), defined as the product of the mean intensity, in fibers per milliliter, the proportion of persons exposed, and the average duration of exposure. Only exposure occurring between the ages of 20 and 59 years was studied (except for cumulative exposure indices, for which exposure was taken into account from the first exposed job), because both the age of entry into the job market and the age of retirement have changed substantially during this century. These changes make age-class or interperiod comparisons for the extreme age classes difficult to perform. To study the changes in asbestos exposure over time, we estimated the principal indicators of exposure distribution by age class (period of birth) and by 10-year age groups; this procedure also allowed us to study the period effect.

Despite the large sample size, some exposure levels and age classes included an insufficient number of subjects for a reliable estimate of the distribution of the exposure variables. We therefore used the bootstrap resampling method (28). The initial sample was boot- strapped 200 times, and for each drawing, each job episode was randomly classified as exposed or not exposed according to the probability assigned by the job-exposure matrix to the corresponding ISCO-ISIC combination. The distribution of the asbestos-exposure variables was estimated from the 200 bootstrapped samples, thereby providing their confidence intervals.

\section{Results}

We first examined the validity of the sample as to its occupational distribution, compared with that of the French male population. The comparison of the proportion of sample subjects classified into principal groups 7,8, and 9 of the ISCO (production and related workers, transport equipment operators and laborers) during the last 5 available censuses, by their age class at that time and the proportion of men in the French general population in the same age class is shown in table 2. No clear trend emerges from the analysis of this table. The chi-square tests performed on 24 cells (and not 25, for the sample did not include any subject older than 55 years in 1954) showed significant differences for 12 cells. When the test was significant, in 8 cases, the proportion of subjects in groups $7-9$ of the ISCO was lower in the sample than in the general population, while the reverse was true for 4 cells. The global chi-square test, for all age classes in each census, was significant 3 times $(1962,1968$, and 1975 ) and not significant twice (1954, 1982). Accordingly no trend could be deciphered. Most important, the percentages were overall reasonably close in that, in 18 of 24 comparisons, the difference was less than $5 \%$. Most of the cases with a spread greater than $5 \%$ ( 4 of 6 ) involved the extreme age classes $(15-24$ years and $55-$ 64 years), which cover entry into and departure from worklife, periods during which it could be difficult to classify subjects in an occupation. It can thus be concluded that, overall, the composition of the sample was as close to that of the French male population as to the distribution of occupations likely to entail workplace asbestos exposure during the period covered by this study.

The sample comprised men questioned between 1984 and 1995. It is censored for the youngest age classes which had not completed worklife at the time of the interview. For these age classes, therefore, we did not have asbestos exposure data for the entire career.

The proportion of men exposed to asbestos in each age class (by period of birth) is shown by 10-year age groups in table 3 . The most-exposed men were those aged $20-29$ years, and the highest proportion of the male population - more than $15 \%$ - was exposed during the 1960 s and 1970 s, a period of expansion for both the French economy and the use of asbestos. For each age 
class, table 4 presents the cumulative proportion of those exposed up to various ages. The age class with a period of birth between $1930-1939$ was, overall, the most heavily exposed, with $24.5 \%$ of all men exposed at least once during their worklife. Comparing the cumulative proportions of those exposed up to the age of 40 years shows that the age classes which entered the workplace around 1950 have the highest proportion of exposed men.

Table 5 presents the mean duration of asbestos exposure by age group among those exposed, by age class. The mean duration of exposure was highest around the 1960 s, when the proportion of those exposed was also highest. Examining the cumulative duration by age class up to various ages (table 6) shows that, among those exposed, the men born before 1950 had the longest period of asbestos exposure.

Table 7 presents the values of the population exposure index, which takes into account the mean level and duration of exposure and the proportion of exposed subjects, by both period of birth and age group. Table 8 reports the cumulative values of this index, by generation, up to various ages. Again, overall asbestos exposure was highest in the 1960s and 1970s, with a maximum for the men born between $1940-1949$ at the ages of $20-29$

Table 2. Proportion of male workers (ISCO groups 7, 8, and 9: production and related workers, transport equipment operators, and laborers, respectively) in the sample and in the censuses.

\begin{tabular}{|c|c|c|c|c|c|c|c|c|c|c|c|c|c|c|c|c|}
\hline \multirow[t]{4}{*}{ Census year } & \multicolumn{15}{|c|}{ Age group } & \multirow{4}{*}{$\begin{array}{l}\text { Chi- } \\
\text { square } \\
\text { testa }\end{array}$} \\
\hline & \multicolumn{3}{|c|}{$15-24$ years } & \multicolumn{3}{|c|}{$25-34$ years } & \multicolumn{3}{|c|}{$35-44$ years } & \multicolumn{3}{|c|}{$45-54$ years } & \multicolumn{3}{|c|}{$55-64$ years } & \\
\hline & \multirow{2}{*}{$\underset{(\%)}{\text { Census }}$} & \multicolumn{2}{|c|}{ Sample } & \multirow{2}{*}{$\begin{array}{c}\text { Census } \\
(\%)\end{array}$} & \multicolumn{2}{|c|}{ Sample } & \multirow{2}{*}{$\begin{array}{c}\text { Census } \\
(\%)\end{array}$} & \multicolumn{2}{|c|}{ Sample } & \multirow{2}{*}{$\begin{array}{c}\text { Census } \\
(\%)\end{array}$} & \multicolumn{2}{|c|}{ Sample } & \multirow{2}{*}{$\begin{array}{c}\text { Census } \\
(\%)\end{array}$} & \multicolumn{2}{|c|}{ Sample } & \\
\hline & & $N$ & $\%$ & & $N$ & $\%$ & & $N$ & $\%$ & & $N$ & $\%$ & & $N$ & $\%$ & \\
\hline \multicolumn{17}{|l|}{$1954^{b}$} \\
\hline Proportion & 45 & 286 & 45.3 & 46.9 & 732 & 43.6 & 41.3 & 370 & 40.8 & 41.6 & 87 & 41.4 & 30.5 & - & - & NS \\
\hline Sample size & . & 631 & . & & 1678 & & . & 906 & . & . & 210 & . & . & . & . & . \\
\hline Testc & . & NS & & & $<0.05$ & 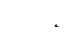 & . & NS & . & . & NS & . & . & - & - & . \\
\hline \multicolumn{17}{|l|}{1962} \\
\hline Proportion & 31.2 & 201 & 36.6 & 51.2 & 617 & 50.1 & 47.5 & 634 & 40.6 & 39.8 & 308 & 37.9 & 32.1 & 54 & 45.4 & $P<0.05$ \\
\hline Sample size & & 549 & . & . & 1231 & . & . & 1560 & . & . & 813 & . & . & & . & . \\
\hline Testc & & $<0.05$ & . & . & NS & . & $\cdot P_{c}$ & $<0.05$ & . & & NS & . & & $0<0.05$ & . & . \\
\hline \multicolumn{17}{|l|}{1968} \\
\hline Proportion & 39.6 & $\begin{array}{l}161 \\
405\end{array}$ & 39.8 & 52 & $\begin{array}{l}387 \\
775\end{array}$ & 49.9 & 48.5 & $\begin{array}{r}654 \\
1486\end{array}$ & 44 & 41.3 & $\begin{array}{r}464 \\
1258\end{array}$ & 36.9 & 30.4 & 186 & 33.1 & $P<0.05$ \\
\hline $\begin{array}{l}\text { Sample size } \\
\text { Test }\end{array}$ & · & 405 & . & . & $7 / 5$ & . & $\cdot$ & 1486 & . & & 1258 & . & & 562 & . & . \\
\hline Test & . & NS & & . & NS & & . $\mathrm{P}_{2} \mathrm{r}_{\mathrm{S}}$ & $<0.05$ & . & & $P<0.05$ & . & & NS & . & . \\
\hline \multicolumn{17}{|l|}{$1975^{\circ}$} \\
\hline Proportion & 35.1 & 75 & 41.7 & 48.5 & 205 & 43.2 & 49.6 & 459 & 46.9 & 42.6 & 623 & 38.3 & 28 & 238 & 23 & $P<0.05$ \\
\hline Sample size & . & 180 & . & . & 474 & & . & 979 & . & . & 1628 & . & & 1037 & . & . \\
\hline Testc & & $<0.05$ & & & $<0.05$ & & & $<0.05$ & . & & $P<0.05$ & . & & $0<0.05$ & . & . \\
\hline \multicolumn{17}{|l|}{$1982^{\circ}$} \\
\hline Proportion & 41.1 & 32 & 43.2 & 42.7 & 115 & 40.2 & 37 & 206 & 37.5 & 36.1 & $\begin{array}{r}496 \\
1231\end{array}$ & 40.3 & 18.2 & $\begin{array}{r}286 \\
1560\end{array}$ & 18.3 & NS \\
\hline $\begin{array}{l}\text { Sample size } \\
\text { Test' }\end{array}$ & . & $\begin{array}{l}74 \\
\text { NS }\end{array}$ & & . & $\begin{array}{r}286 \\
\text { NS }\end{array}$ & & . & $\begin{array}{r}549 \\
\text { NS }\end{array}$ & . & $P$ & $\begin{array}{r}1231 \\
P<0.05\end{array}$ & . & & $\begin{array}{r}1560 \\
\text { NS }\end{array}$ & $\cdot$ & $\cdot$ \\
\hline & & No & & ' & NOS & & . & No & . & & $r<0.00$ & . & & & & . \\
\hline
\end{tabular}

a Global test for all age classes.

$20-24$ years.

- Comparison between the census and sample proportions.

$17-24$ years.

Table 3. Proportion of men exposed to asbestos at least once during a period (listed by midyear) by age class (period of birth) and age groups in France. (95\% $\mathrm{Cl}=95 \%$ confidence interval)

\begin{tabular}{|c|c|c|c|c|c|c|c|c|c|c|c|c|}
\hline \multirow[t]{3}{*}{ Period of birth } & \multicolumn{12}{|c|}{ Age group } \\
\hline & \multicolumn{3}{|c|}{$20-29$ years } & \multicolumn{3}{|c|}{$30-39$ years } & \multicolumn{3}{|c|}{$40-49$ years } & \multicolumn{3}{|c|}{$50-59$ years } \\
\hline & $\begin{array}{c}\text { Proportion } \\
(\%)\end{array}$ & $95 \% \mathrm{Cl}$ & $\begin{array}{l}\text { Mid- } \\
\text { yearar }^{2}\end{array}$ & $\begin{array}{c}\text { Proportion } \\
(\%)\end{array}$ & $95 \% \mathrm{Cl}$ & $\begin{array}{l}\text { Mid- } \\
\text { yeara }\end{array}$ & $\begin{array}{c}\text { Proportion } \\
(\%)\end{array}$ & $95 \% \mathrm{Cl}$ & $\begin{array}{l}\text { Mid- } \\
\text { yeara }\end{array}$ & $\begin{array}{c}\text { Proportion } \\
(\%)\end{array}$ & $95 \% \mathrm{Cl}$ & $\begin{array}{l}\text { Mid- } \\
\text { yeara }\end{array}$ \\
\hline $1900-1909$ & 12 & $7--16$ & 1930 & 10 & $6-15$ & 1940 & 8 & $5-12$ & 1950 & 8 & $4-13$ & 1960 \\
\hline $1910-1919$ & 10 & $7--12$ & 1940 & 10 & $7-12$ & 1950 & 9 & $7-11$ & 1960 & 7 & $5-9$ & 1970 \\
\hline $1920-1929$ & 13 & $11-14$ & 1950 & 11 & $9-13$ & 1960 & 9 & $7-11$ & 1970 & 7 & $5-8$ & 1980 \\
\hline $1930-1939$ & 15 & $13--17$ & 1960 & 12 & $10-14$ & 1970 & 11 & $9-13$ & 1980 & 4 & $3-5$ & 1990 \\
\hline $1940-1949$ & 15 & $11--18$ & 1970 & 10 & $7-13$ & 1980 & 3 & $2-5$ & 1990 & & & \\
\hline $1950-1959$ & 13 & $8-17$ & 1980 & 6 & $3-10$ & 1990 & .. & . & .. & .. & . & .. \\
\hline $1960-1969$ & 6 & $2-10$ & 1990 & .. & . & .. & .. & . & .. & .. & . & .. \\
\hline
\end{tabular}

a of the corresponding period. 
Table 4. Cumulative proportion of men exposed to asbestos by age class (period of birth) at different ages in France. $(95 \% \mathrm{Cl}=95 \%$ confidence interval)

\begin{tabular}{|c|c|c|c|c|c|c|c|c|c|c|c|c|}
\hline \multirow[t]{3}{*}{ Period of birth } & \multicolumn{12}{|c|}{ Age } \\
\hline & \multicolumn{3}{|c|}{30 years } & \multicolumn{3}{|c|}{40 years } & \multicolumn{3}{|c|}{50 years } & \multicolumn{3}{|c|}{60 years } \\
\hline & $\begin{array}{c}\text { Cumulative } \\
\text { proportion } \\
(\%)\end{array}$ & $95 \% \mathrm{Cl}$ & $\begin{array}{l}\text { Mid- } \\
\text { yeara }^{\text {a }}\end{array}$ & $\begin{array}{c}\text { Cumulative } \\
\text { proportion } \\
(\%)\end{array}$ & $95 \% \mathrm{Cl}$ & $\begin{array}{l}\text { Mid- } \\
\text { yeara }\end{array}$ & $\begin{array}{c}\text { Cumulative } \\
\text { proportion } \\
(\%)\end{array}$ & $95 \% \mathrm{Cl}$ & $\begin{array}{l}\text { Mid- } \\
\text { yeara }\end{array}$ & $\begin{array}{c}\text { Cumulative } \\
\text { proportion } \\
(\%)\end{array}$ & $95 \% \mathrm{Cl}$ & $\begin{array}{l}\text { Mid- } \\
\text { yeara }\end{array}$ \\
\hline $1900-1909$ & 15 & $10-21$ & 1935 & 17 & $11-23$ & 1945 & 19 & $13-25$ & 1955 & 20 & $14-26$ & 1965 \\
\hline $1910-1919$ & 13 & $11-16$ & 1945 & 16 & $13-19$ & 1955 & 17 & $15-20$ & 1965 & 18 & $15-21$ & 1975 \\
\hline $1920-1929$ & 16 & $14-18$ & 1955 & 19 & $17-21$ & 1965 & 20 & $18-22$ & 1975 & 21 & $19-23$ & 1985 \\
\hline $1930-1939$ & 20 & $17-22$ & 1965 & 23 & $20-25$ & 1975 & 24 & $21-27$ & 1985 & 24 & $22-27$ & 1995 \\
\hline $1940-1949$ & 20 & $16-24$ & 1975 & 22 & $18-26$ & 1985 & 22 & $19-26$ & 1995 & .. & . & .. \\
\hline $1950-1959$ & 17 & $11-22$ & 1985 & 18 & $13-23$ & 1995 & .. & 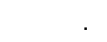 &.. & .. & . & .. \\
\hline $1960-1969$ & 9 & $5-15$ & 1995 & .. & & .. & .. & . & .. & .. & . & .. \\
\hline
\end{tabular}

${ }^{a}$ Of the corresponding period.

Table 5. Mean duration of exposure to asbestos among the men by age class (period of birth) and age group in France. $(95 \% \mathrm{Cl}=95 \%$ confidence interval)

\begin{tabular}{|c|c|c|c|c|c|c|c|c|c|c|c|c|}
\hline \multirow[t]{4}{*}{ Period of birth } & \multicolumn{12}{|c|}{ Age group } \\
\hline & \multicolumn{3}{|c|}{$20-29$ years } & \multicolumn{3}{|c|}{$30-39$ years } & \multicolumn{3}{|c|}{$40-49$ years } & \multicolumn{3}{|c|}{$50-59$ years } \\
\hline & \multicolumn{2}{|c|}{$\begin{array}{c}\text { Duration } \\
\text { of } \\
\text { exposure }\end{array}$} & \multirow[t]{2}{*}{$\begin{array}{l}\text { Mid- } \\
\text { year }\end{array}$} & \multicolumn{2}{|c|}{$\begin{array}{l}\text { Duration } \\
\text { of } \\
\text { exposure }\end{array}$} & \multirow[t]{2}{*}{$\begin{array}{l}\text { Mid- } \\
\text { year }\end{array}$} & \multicolumn{2}{|c|}{$\begin{array}{c}\text { Duration } \\
\text { of } \\
\text { exposure }\end{array}$} & \multirow[t]{2}{*}{$\begin{array}{l}\text { Mid- } \\
\text { year }^{\text {a }}\end{array}$} & \multicolumn{2}{|c|}{$\begin{array}{c}\text { Duration } \\
\text { of } \\
\text { exposure }\end{array}$} & \multirow[t]{2}{*}{$\begin{array}{l}\text { Mid- } \\
\text { yeara }^{2}\end{array}$} \\
\hline & Mean & $95 \% \mathrm{Cl}$ & & Mean & $95 \% \mathrm{Cl}$ & & Mean & $95 \% \mathrm{Cl}$ & & Mean & $95 \% \mathrm{Cl}$ & \\
\hline $1900-1909$ & 5.6 & $4.1-6.8$ & 1930 & 6.2 & $4.6-7.9$ & 1940 & 8.2 & $6.8-9.3$ & 1950 & 8.4 & $6.9-9.6$ & 1960 \\
\hline $1910-1919$ & 5 & $4.3-5.7$ & 1940 & 6.6 & $5.9-7.2$ & 1950 & 7.6 & $6.8-8.3$ & 1960 & 7.8 & $7-8.5$ & 1970 \\
\hline $1920-1929$ & 5 & $4.6-5.4$ & 1950 & 7.0 & $6.5-7.6$ & 1960 & 7.5 & $6.9-8.1$ & 1970 & 5.9 & $5.3-6.5$ & 1980 \\
\hline $1930-1939$ & 5.2 & $4.7-5.8$ & 1960 & 7.2 & $6.6-7.8$ & 1970 & 6.5 & $5.8-7.7$ & 1980 & 4.2 & $3.4-5$ & 1990 \\
\hline $1940-1949$ & 5.2 & $4.3-5.9$ & 1970 & 6 & $5-6.9$ & 1980 & 4.6 & $3.3-6$ & 1990 & .. & . & .. \\
\hline $1950-1959$ & 4.3 & $2.8-5.5$ & 1980 & 4.7 & $3.1-6.5$ & 1990 & .. & 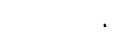 & .. & .. & . & .. \\
\hline $1960-969$ & 3.7 & $1.7-5.5$ & 1990 & .. & . & .. & .. & . & .. & .. & . & .. \\
\hline
\end{tabular}

a Of the corresponding period.

Table 6. Mean cumulative duration of exposure to asbestos among the men by age class (period of birth) at different ages in France. $(95 \% \mathrm{Cl}=95 \%$ confidence interval)

\begin{tabular}{|c|c|c|c|c|c|c|c|c|c|c|c|c|}
\hline \multirow[t]{4}{*}{ Period of birth } & \multicolumn{12}{|c|}{ Age } \\
\hline & \multicolumn{3}{|c|}{30 years } & \multicolumn{3}{|c|}{40 years } & \multicolumn{3}{|c|}{50 years } & \multicolumn{3}{|c|}{60 years } \\
\hline & \multicolumn{2}{|c|}{$\begin{array}{c}\text { Cumulative } \\
\text { duration } \\
\text { of } \\
\text { exposure }\end{array}$} & \multirow[t]{2}{*}{$\begin{array}{l}\text { Mid- } \\
\text { yeara }\end{array}$} & \multicolumn{2}{|c|}{$\begin{array}{c}\text { Cumulative } \\
\text { duration } \\
\text { of } \\
\text { exposure }\end{array}$} & \multirow[t]{2}{*}{$\begin{array}{l}\text { Mid- } \\
\text { year }^{3}\end{array}$} & \multicolumn{2}{|c|}{$\begin{array}{c}\text { Cumulative } \\
\text { duration } \\
\text { of } \\
\text { exposure }\end{array}$} & \multirow[t]{2}{*}{$\begin{array}{l}\text { Mid- } \\
\text { yeara }\end{array}$} & \multicolumn{2}{|c|}{$\begin{array}{c}\text { Cumulative } \\
\text { duration } \\
\text { of } \\
\text { exposure }\end{array}$} & \multirow[t]{2}{*}{$\begin{array}{l}\text { Mid- } \\
\text { year }\end{array}$} \\
\hline & $\begin{array}{l}\text { Mean } \\
\text { cumulative } \\
\text { duration }\end{array}$ & $95 \% \mathrm{Cl}$ & & $\begin{array}{l}\text { Mean } \\
\text { cumulative } \\
\text { duration }\end{array}$ & $95 \% \mathrm{Cl}$ & & $\begin{array}{c}\text { Mean } \\
\text { cumulative } \\
\text { duration }\end{array}$ & $95 \% \mathrm{Cl}$ & & $\begin{array}{c}\text { Mean } \\
\text { cumulative } \\
\text { duration }\end{array}$ & $95 \% \mathrm{Cl}$ & \\
\hline $1900-1909$ & 7.4 & $5.9-9.5$ & 1935 & 10.1 & $7.4-13.1$ & 1945 & 12.7 & $9.2-16.1$ & 1955 & 15.4 & $11.3-19.5$ & 1965 \\
\hline $1910-1919$ & 6.5 & $5.5-7.4$ & 1945 & 9.4 & $8.1-10.6$ & 1955 & 12.4 & $10.4-1.4 .2$ & 1965 & 14.7 & $12.4-16.7$ & 1975 \\
\hline $1920-1929$ & 5.8 & $5.3-6.3$ & 1955 & 8.9 & $8.1-9.6$ & 1965 & 11.8 & $10.6-12.8$ & 1975 & 13.3 & $11.9-14.4$ & 1985 \\
\hline $1930-1939$ & 6.1 & $5.4-6.7$ & 1965 & 9.1 & $8-10.1$ & 1975 & 11.1 & $9.9-12.4$ & 1985 & 11.6 & $10.2-12.9$ & 1995 \\
\hline $1940-1949$ & 5.9 & $5-6.7$ & 1975 & 8 & $6.8-9.4$ & 1985 & 8.5 & $7-9.9$ & 1995 & .. & . & .. \\
\hline $1950-1959$ & 5.1 & $3.7-6.6$ & 1985 & 6.1 & $4.3-8$ & 1995 & .. & . & .. & .. & . & .. \\
\hline $1960-1969$ & 3.4 & $1.8-5.7$ & 1995 & .. & 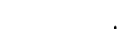 & .. & .. & & .. & .. & . & .. \\
\hline
\end{tabular}

a of the corresponding period. 
years (PEI 0.2). When the cumulative value of the population exposure index is considered up to the age of 60 years, it appears that the men born in 1920-1929 were the most heavily exposed (PEI 0.4). Only the generations born after 1950 show a substantial reduction in their exposure to asbestos. In other words, in France, it is the men aged 45 years or older today who have been the most massively exposed.

The evolution of exposure to asbestos over time in France between 1930 and 1990 (earlier periods were not included, due to the small number of subjects in the sample) is summarized in table 9. The mean values of the percentage of men exposed at least once, of the duration of exposure among those exposed, and of the population exposure index were computed by 10 -year periods for men aged $20-59$ years. The total percentage of exposed men was highest between 1940 and 1960 (over 12\%), and it decreased after this period. However, the mean duration of exposure to asbestos increased strongly from 1950 to 1980 , explaining that the population exposure index reached its highest value between 1960 and 1970. This index decreased rapidly after 1970 , due partly to the decrease of the prevalence of exposure, and mainly to the lowering of exposure levels.

\section{Discussion}

A sizeable sample of men and the use of a specific job-exposure matrix for asbestos have enabled the

Table 7. Mean value of the population exposure index for the men by age class (period of birth) and age group in France. $(95 \% \mathrm{Cl}=95 \%$ confidence interval)

\begin{tabular}{|c|c|c|c|c|c|c|c|c|c|c|c|c|}
\hline \multirow[t]{4}{*}{ Period of birth } & \multicolumn{12}{|c|}{ Age group } \\
\hline & \multicolumn{3}{|c|}{$20-29$ years } & \multicolumn{3}{|c|}{$30-39$ years } & \multicolumn{3}{|c|}{$40-49$ years } & \multicolumn{3}{|c|}{$50-59$ years } \\
\hline & \multicolumn{2}{|c|}{$\begin{array}{l}\text { Population } \\
\text { exposure } \\
\text { index }\end{array}$} & \multirow[t]{2}{*}{$\begin{array}{l}\text { Mid- } \\
\text { year }^{\text {a }}\end{array}$} & \multicolumn{2}{|c|}{$\begin{array}{l}\text { Population } \\
\text { exposure } \\
\text { index }\end{array}$} & \multirow[t]{2}{*}{$\begin{array}{l}\text { Mid- } \\
\text { yeara }\end{array}$} & \multicolumn{2}{|c|}{$\begin{array}{l}\text { Population } \\
\text { exposure } \\
\text { index }\end{array}$} & \multirow[t]{2}{*}{$\begin{array}{l}\text { Mid- } \\
\text { year }\end{array}$} & \multicolumn{2}{|c|}{$\begin{array}{l}\text { Population } \\
\text { exposure } \\
\text { index }\end{array}$} & \multirow[t]{2}{*}{$\begin{array}{l}\text { Mid- } \\
\text { year }^{\mathrm{a}}\end{array}$} \\
\hline & $\begin{array}{c}\text { Mean } \\
\text { cumulative } \\
\text { value }\end{array}$ & $95 \% \mathrm{Cl}$ & & $\begin{array}{l}\text { Mean } \\
\text { cumulative } \\
\text { value }\end{array}$ & $95 \% \mathrm{Cl}$ & & $\begin{array}{c}\text { Mean } \\
\text { cumulative } \\
\text { value }\end{array}$ & $95 \% \mathrm{Cl}$ & & $\begin{array}{c}\text { Mean } \\
\text { cumulative } \\
\text { value }\end{array}$ & $95 \% \mathrm{Cl}$ & \\
\hline $1900-1909$ & 0.1 & $0.0-0.1$ & 1930 & 0.1 & $0.0-0.1$ & 1940 & 0.0 & $0.0-0.01$ & 1950 & 0.0 & $0.0-0.1$ & 1960 \\
\hline $1910-1919$ & 0.1 & $0.0-0.1$ & 1940 & 0.1 & $0.0-0.1$ & 1950 & 0.1 & $0.05-0.1$ & 1960 & 0.0 & $0.0-0.1$ & 1970 \\
\hline $1920-1929$ & 0.2 & $0.1-0.3$ & 1950 & 0.1 & $0.0-0.2$ & 1960 & 0.1 & $0.05-0.2$ & 1970 & 0.0 & $0.0-0.05$ & 1980 \\
\hline $1930-1939$ & 0.2 & $0.1-0.3$ & 1960 & 0.1 & $0.1-0.2$ & 1970 & 0.1 & $0.05-0.1$ & 1980 & 0.0 & $0.0-0.01$ & 1990 \\
\hline $1940-1949$ & 0.2 & $0.1-0.3$ & 1970 & 0.1 & $0.1-0.2$ & 1980 & 0.01 & $0.0-0.01$ & 1990 & .. & & .. \\
\hline $1950-1959$ & 0.1 & $0.0-0.1$ & 1980 & 0.01 & $0.0-0.02$ & 1990 &.. & . & .. & .. & & .. \\
\hline $1960-1969$ & 0.01 & $0.0-0.02$ & 1990 & .. & . & .. & .. & . & .. & .. & . & .. \\
\hline
\end{tabular}

a 0 the corresponding period.

Table 8. Mean cumulative value of the population exposure index for the men at different ages by age class (period of birth) in France. $(95 \% \mathrm{Cl}=95 \%$ confidence interval)

\begin{tabular}{|c|c|c|c|c|c|c|c|c|c|c|c|c|}
\hline \multirow[t]{4}{*}{ Period of birth } & \multicolumn{12}{|c|}{ Age } \\
\hline & \multicolumn{3}{|c|}{30 years } & \multicolumn{3}{|c|}{40 years } & \multicolumn{3}{|c|}{50 years } & \multicolumn{3}{|c|}{60 years } \\
\hline & \multicolumn{2}{|c|}{$\begin{array}{l}\text { Cumulative } \\
\text { population } \\
\text { exposure } \\
\text { index }\end{array}$} & \multirow[t]{2}{*}{$\begin{array}{l}\text { Mid- } \\
\text { year }^{\mathrm{a}}\end{array}$} & \multicolumn{2}{|c|}{$\begin{array}{c}\text { Cumulative } \\
\text { population } \\
\text { exposure } \\
\text { index }\end{array}$} & \multirow[t]{2}{*}{$\begin{array}{l}\text { Mid- } \\
\text { year }^{2}\end{array}$} & \multicolumn{2}{|c|}{$\begin{array}{c}\text { Cumulative } \\
\text { population } \\
\text { exposure } \\
\text { index }\end{array}$} & \multirow[t]{2}{*}{$\begin{array}{l}\text { Mid- } \\
\text { yeara }\end{array}$} & \multicolumn{2}{|c|}{$\begin{array}{c}\text { Cumulative } \\
\text { population } \\
\text { exposure } \\
\text { index }\end{array}$} & \multirow[t]{2}{*}{$\begin{array}{l}\text { Mid- } \\
\text { year }^{2}\end{array}$} \\
\hline & $\begin{array}{l}\text { Mean } \\
\text { cumulative } \\
\text { value }\end{array}$ & $95 \% \mathrm{Cl}$ & & $\begin{array}{c}\text { Mean } \\
\text { cumulative } \\
\text { value }\end{array}$ & $95 \% \mathrm{Gl}$ & & $\begin{array}{l}\text { Mean } \\
\text { cumulative } \\
\text { value }\end{array}$ & $95 \% \mathrm{Cl}$ & & $\begin{array}{c}\text { Mean } \\
\text { cumulative } \\
\text { value }\end{array}$ & $95 \% \mathrm{Cl}$ & \\
\hline $1900-1909$ & 0.1 & $0.0-0.3$ & 1935 & 0.2 & $0.1-0.5$ & 1945 & 0.2 & $0.1-0.6$ & 1955 & 0.3 & $0.1-0.7$ & 1965 \\
\hline $1910-1919$ & 0.1 & $0.1-0.2$ & 1945 & 0.2 & $0.1-0.3$ & 1955 & 0.3 & $0.2-0.4$ & 1965 & 0.3 & $0.2-0.4$ & 1975 \\
\hline $1920-1929$ & 0.2 & $0.1-0.4$ & 1955 & 0.3 & $0.2-0.6$ & 1965 & 0.4 & $0.2-0.6$ & 1975 & 0.4 & $0.2-0.7$ & 1985 \\
\hline $1930-1939$ & 0.2 & $0.1-0.3$ & 1965 & 0.3 & $0.1-0.4$ & 1975 & 0.3 & $0.2-0.5$ & 1985 & 0.3 & $0.2-0.5$ & 1995 \\
\hline $1940-1949$ & 0.2 & $0.1-0.3$ & 1975 & 0.3 & $0.1-0.5$ & 1985 & 0.3 & $0.1-0.6$ & 1995 & .. & . & .. \\
\hline $1950-1959$ & 0.05 & $0.0-0.1$ & 1985 & 0.1 & $0.0-0.1$ & 1995 & .. & . & .. & .. & . & .. \\
\hline $1960-1969$ & 0.0 & $0.0-0.01$ & 1995 & .. & . & .. & .. & . & .. & .. & . & .. \\
\hline
\end{tabular}

a the corresponding period. 
Table 9. Mean value and $95 \%$ confidence interval $(95 \% \mathrm{Cl})$ for the different exposure indices by midyear of the period in question among the men aged $20-59$ years in France.

\begin{tabular}{|c|c|c|c|c|c|c|c|c|}
\hline \multirow[t]{2}{*}{$\begin{array}{l}\text { Midyear of } \\
\text { the period }\end{array}$} & \multicolumn{2}{|c|}{ Number } & \multicolumn{2}{|c|}{$\begin{array}{l}\text { Percentage of men } \\
\text { exposed at least once }\end{array}$} & \multicolumn{2}{|c|}{ Duration of exposure } & \multicolumn{2}{|c|}{ Population exposure index } \\
\hline & Mean ${ }^{a}$ & $95 \% \mathrm{Cl}$ & Mean & $95 \% \mathrm{Cl}$ & Mean & $95 \% \mathrm{Cl}$ & Mean & $95 \% \mathrm{Cl}$ \\
\hline 1935 & 1198 & $1146-1257$ & 10.8 & $8.8-12.4$ & 4 & $3.6-4.5$ & 0.06 & $0.03-0.08$ \\
\hline 1945 & 2737 & $2677-2796$ & 12.6 & $11.3-14.1$ & 4.2 & $3.8-4.5$ & 0.10 & $0.06-0.16$ \\
\hline 1955 & 3628 & $3575-3672$ & 12.4 & $11.4-13.6$ & 5.8 & $5.4-6.1$ & 0.10 & $0.08-0.14$ \\
\hline 1965 & 4023 & $3991-4055$ & 11.4 & $10.3-12.4$ & 6.5 & $6.2-6.8$ & 0.11 & $0.06-0.17$ \\
\hline 1975 & 3885 & $3849-3918$ & 9.3 & $8.3-10.2$ & 6.4 & $6.1-6.7$ & 0.06 & $0.04-0.09$ \\
\hline 1985 & 2935 & $2876-2987$ & 5.1 & $4.3-5.9$ & 4.7 & $4.2-5.1$ & 0.01 & $0.01-0.01$ \\
\hline
\end{tabular}

a Mean number of subjects aged 20-59 years in the sample during the period

reconstruction of occupational exposure to asbestos and its development in France since the beginning of the century. This reconstruction provides information, by age class (10-year periods of birth) and age group, about the principal characteristics of exposure associated with cancer risk: frequency, duration, and level. These data could be used to model the trends in mesothelioma mortality among French men over the next decades. However, various problems related to the validity of the estimates presented merit discussion.

The representativeness of the sample in relation to the overall French male population was analyzed in terms of occupations likely to entail asbestos exposure, and the sample used for this study was very close to the general population for the various periods that were considered. This similarity is probably explained by the fact that the sample was drawn from population-based case-referent studies in a variety of regions covering most of France. One might nonetheless have expected a selection bias since, for each age class, it was those who survived into the 1980s and 1990s who were interviewed. Because mortality is higher among workers than among more well-to-do classes, this "healthy survivor effect" should thus have tended to underestimate asbestos exposure in the general population. Nonetheless, since the mean age of the sample at interview was only 59.2 years, this bias was probably minimal. In particular, the comparison of the frequency of men in ISCO groups 7-9 in the sample and the general population showed no significant differences for the most recent census (1982).

Despite the size of this sample, only a few subjects represented the oldest and youngest age classes. This representation reduced the precision of the estimates. Using the bootstrap method showed, however, that the confidence intervals were fairly narrow and hence that the estimates of the exposure indices were relatively precise. Another problem is that the sample included the different age classes interviewed during the same period; it is accordingly censored for the youngest generations. Because we were concerned only with past exposure, however, this censoring did not affect our results.
The characteristics by which asbestos exposure has been assessed come from a job-exposure matrix. Hence, the validity of the estimates of past exposure and of their trends are closely linked to the accuracy of the job-exposure matrix and especially to its ability to describe the changes that have occurred over time. The job-exposure matrix was constructed using knowledge from different sources of data and expertise, mainly trends in imports of asbestos, modifications in technology and working processes in the various economic sectors, and changes in regulations about the protection of workers and asbestos use. The design of the matrix allowed changes that were likely to modify exposure conditions to be taken into account by changing the probability, the level, or the frequency of exposure. Cut-off points were chosen according to different criteria, and they were specific for each ISCO-ISIC combination. For instance, the job-exposure matrix contains 476 different entries associated with the ISIC code 5000 (construction), which is a key sector regarding asbestos exposure. They correspond to 272 different ISCO codes, 66 of them being divided into 2 different time periods, 7 into 3 periods, 18 into 4 periods, and 11 into 5 or more periods. The cut-off points varied from 1930 to 1980 , depending on the reason for changing the value of one or more exposure indices. This feature of the matrix allows for more-detailed exposure assessments over time for different occupations than what would have been derived only from gross asbestos import figures.

Variations in asbestos exposure are indeed linked to asbestos imports, since almost all the asbestos used in France was imported. How close the correlation is in time between the quantity of asbestos in a country (reflected by cumulative import figures) and the way the workers are exposed to asbestos is nevertheless not clear. Before 1937 (first year for which data are available), the quantity of asbestos imports, which had begun at the end of the last century, was probably low. Figure 1 shows the evolution from 1937 to 1994 of annual asbestos imports (Association Française de l'Amiante, personal communication). After a break during World War II, imports 
increased steeply, reaching their peak in 1975, and then decreased, ending finally in 1996 when asbestos use was banned by the French government. Almost no information is available about the type of asbestos imported (data are known only for a small fraction of total imports and not for all years; see figure 1), but chrysotile seems to have been the most common. Estimates of the exposure indices in this study are not directly comparable to the quantities of annual imports of asbestos in France. Table 9 shows that the mean duration and level of exposure were low during the 1930s when imports were probably not so important, but that prevalence was already high. This situation can be explained by the fact that the jobexposure matrix overestimated the frequency of exposed jobs in the remote past. However, mesothelioma mortality in France increased sharply from the 1950s on (29). Due to the latency period, this trend would be consistent with a significant exposure prevalence during the 1930s. Table 9 also shows that the mean population exposure index has been high since the 1940s, namely, at the beginning of the rise in asbestos imports. Again, this phenomenon could be due to an overestimation of exposure by the job-exposure matrix. Another explanation may be that, even if the annual quantity of imports was still low, the cumulated quantity of asbestos was already high. Moreover, exposure levels increased rapidly in the postWorld War II period, due to the expansion of the French economy and to the absence of efficient protective regulations. Finally, yearly asbestos import figures do not correlate directly with trends in population exposure, since they do not take into account changes in some important determinants of the workers' exposure, and the main features of exposure among workers cannot be simply derived from import figures.
It must also be considered that a job-exposure matrix is an imperfect tool that can result in individual misclassification (30). Various epidemiologic studies of the effects of asbestos exposure have nonetheless used this method with satisfactory results $(26,31,32)$. The "epidemiologic performance" of this matrix can also be more formally assessed, by comparing its results with those obtained for the same subjects with a reference exposure assessment method (33). The epidemiologic performance of the job-exposure matrix used in this work was assessed by the comparison of 2 series of odds ratios. Both derive from the population-based case-referent study of mesothelioma recently carried out in France by Iwatsubo et al (9). This study included 460 cases and 421 referents. One series was obtained for asbestos exposure as assessed by the job-exposure matrix, and the other for exposure assessment by a group of industrial hygienists on a caseby-case basis (Iwatsubo Y, Orlowski E, personal communication). The comparison of the odds ratios for each of the methods showed that the values obtained with both were, on the whole, consistent. For example, the odds ratios associated with an estimated cumulative exposure of $0.5-0.99$ fibers per milliliter per year were 4.7 [95\% confidence interval $(95 \% \mathrm{CI}) 2.5-8.7$ ] for the case-by case expertise and 2.8 (95\% CI 1.4-5.6) for the job-exposure matrix assessment. They were respectively 5.4 (95\% CI 2.7-10.8) and 10.1 (95\% CI 2.9-35.5) when the cumulative exposure was $2.5-4.9$ fibers per milliliter per year, 8.5 (95\% CI 2.3-30.8), and 3.0 (95\% CI $0.7-12.1$ ) when the cumulative exposure was $10-19.9$ fibers per milliliter per year, and 10.2 (95\% CI 4.8-21.9) and 14.0 (95\% Cl 3.2-62.1) when the cumulative exposure was over 20 fibers per milliliter per year. Thus the use of the job-exposure matrix for assessing

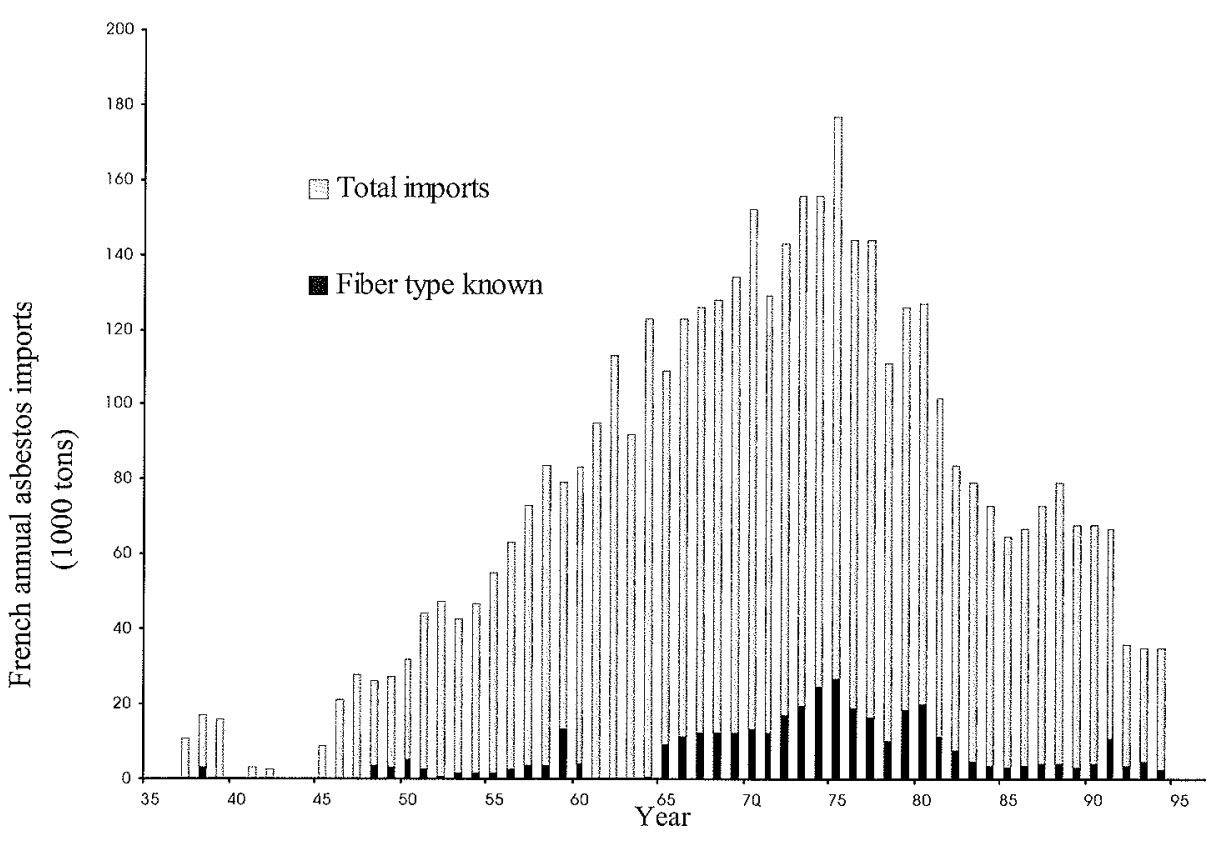

Figure 1. Asbestos imports into France since 1937 and the proportion for which the mineralogical type is known. 
exposure probably did not lead to any major distortion in the estimates of the population's exposure to asbestos.

Beyond the figures concerning the production, importation, or use of asbestos in the principal industries of various countries, little is currently known about the distribution of asbestos exposure among various national populations. The proportion of men occupationally exposed to asbestos has been estimated to vary from $10 \%$ to $36 \%$ in Sweden and Norway, whereas $18 \%$ of Finnish men 35 years or older have been significantly exposed (13). These data are consistent with those presented in this report. Despite the imprecision inherent in the limitations of available data and tools, this study brings information of reasonable validity about occupational asbestos exposure in France and its trends over the past century. These data are currently being used to model the changes in male mortality from mesothelioma in France in the decades to come.

\section{Acknowledgments}

We thank S Benhamou, J Clavel, S Cordier, M Hours, Y Iwatsubo, S Richardson, B Stengel, and I Stucker, who have furnished the individual occupational history data used in this study. We thank especially E Orlowski, who allowed us to use the job-exposure matrix that she developed, who added to the matrix for this study, and who, together with Y Iwatsubo, to whom we also extend special thanks, allowed us to cite some results of the comparison of mesothelioma risks associated with asbestos exposure, as assessed by individual expert evaluations and by the job-exposure matrix used in this work. This work was supported by grants from the French Ministère du Travail and La Ligue Nationale contre le Cancer.

\section{References}

1. International Agency for Research on Cancer (IARC). Overall evaluation of carcinogenicity: an updating of IARC monographs, volumes 1-42. Lyon: IARC, 1987. IARC monographs on the evaluation of carcinogenic risks to humans, supplement 7 .

2. McDonald JC, McDonald AD. The epidemiology of mesothelioma in historical context. Eur Respir J 1996;9:1932-42.

3. Lemen RA, Dement JM, Wagoner JK. Epidemiology of asbestos-related diseases. Environ Health Perspect 1980;34:111.

4. Gardner MJ, Saracci R. Effects on health of non-occupational exposure to airborne mineral fibers. In: Bignon J, Peto J, Saracci R, editors. Non-occupational exposure to mineral fibers. Lyon: International Agency for Research on Cancer, 1989:375-97. IARC scientific publications, no 90.
5. De Vita V, Hellman S, Rosenberg S. Cancer: principles in practice of oncology. 5th ed. Philadelphia-New York: Lippincott-Raven, 1997.

6. Vineis P. Simonato L. Proportion of lung and bladder cancers in male resulting from occupation: a systematic approach. Arch Environ Health 1991;46:6-15.

7. McDonald AD, McDonald JC. Malignant mesothelioma in North America. Cancer 1980;4:1650-6.

8. Peto J, Hodgson JT, Matthews FE, Jones JR. Continuing increase in mesothelioma mortality in Britain. Lancet 1995; 345:535-9.

9. Iwatsubo Y, Pairon JC, Boutin C, Martinet Y, Caillaud D, Bignon J, et al. Pleural mesothelioma: dose-response relationship at low level of asbestos exposure in a population-based case-control study. Am J Epidemiol 1998;148:133-42.

10. McDonald JC. Epidemiology of pleural cancer. In: Hirsch A, Goldberg M, Martin JP, Masse R, editors. Prevention of respiratory diseases (lung biology in health and disease). New York (NY): Marcel Dekker, 1993:65-79.

11. Merler E, Buiatti E, Vaino H. Surveillance and intervention studies on respiratory cancers in asbestos-exposed workers [review]. Scand J Work Environ Health 1997;23:83-92.

12. Peto J, Decarli A, La Vecchia C, Levi F, Negri E. The European mesothelioma epidemic. Br J Cancer 1999;79(3/4):66672.

13. Albin M, Shefer I, Magnani C, Krstev S. Asbestos and cancer. Med Lav 1994;86 suppl:259-62.

14. International Labour Office (ILO). International standard classification of occupations: ISCO-68. Geneva: ILO, 1968.

15. United Nations. International standard industrial classification of all economic activities. New York (NY): United Nations, 1971.

16. Boffetta P, Agudo A, Ahrens W, Benhamou E, Benhamou S, Darby $S$, et al. Multicenter case-control study of exposure to environmental tobacco smoke and lung cancer in Europe. JNCI 1998;90:1440—50.

17. Clavel J, Mandereau L, Cordier S, Le Goaster C, Hemon D, Conso F, et al. Hairy cell leukaemia, occupation and smoking. Br J Haematol 1995;91:154-61.

18. Cordier S, Clavel J, Limasset JC, Boccon-Gibod L, Le Moual $\mathrm{N}$, Mandereau L, et al. Occupational risks of bladder cancer in France: a multicentre case-control study. Int J Epidemiol 1993; 22:403-11.

19. Hours M, Dananche B, Caillat-Vallet E, Fevotte J, Philippe J, Boiron $O$, et al. Glycol ethers and myeloid acute leukaemia: a multicenter case-control study. Occup Hyg 1996;2:405-10.

20. Hours M, Dananche B, Fevotte J, Bergeret A, Ayzac L, Cardis $\mathrm{E}$, et al. Bladder cancer and occupational exposures. Scand J Work Environ Health 1994;20:322-30.

21. Hours M, Fevotte J, Dananche B. Lung cancer and occupational risk: results of a case-control study conducted in Lyon (1984-1990). Presented at the 8th International Symposium in Epidemiology in Occupational Health, Paris, 10-12 September 1991.

22. Luce D, Gerin M, Leclerc A, Morcet JF, Brugere J, Goldberg $M$. Sinonasal cancer and occupational exposure to formaldehyde and other substances. Int J Cancer 1993;53:224-31.

23. Richardson S, Zittoun R, Bastuji-Garin S, Lasserre V, Guihenneuc $\mathrm{C}$, Cadiou $\mathrm{M}$, et al. Occupational risk factors for acute leukaemia: a case-control study. Int J Epidemiol 1992; 21:1063-73.

24. Stengel I, Cénée S, Limasset JC, Protois JC, Marcelli A, Brochard $\mathrm{P}$, et al. Organic solvent exposure may increase the risk of glomerular nephropathies with chronic renal failure. 
Int J Epidemiol 1995;24:427-34.

25. Stucker I, Cosme J, Laurent $P$, Cenee $S$, Beaune P, Bignon J, et al. CYP2D6 genotype and lung cancer risk according to histologic type and tobacco exposure. Carcinogenesis 1995; (V/P) 16:2759-64.

26. Orlowski E, Pohlabeln H, Berrino F, Ahrens W, Bolm-Audorff $U$, Grossgarten $\mathrm{K}$, et al. Retrospective assessment of asbestos exposure at the job level: complementarity of jobspecific questionnaires and job-exposure matrices. Int J Epidemiol 1993;22:S96-S105.

27. National Institute for Statistics and Economic Studies (INSEE). Classification of socioprofessional categories, PCS. Paris: INSEE, 1983. In French.

28. Effron B. Better bootstrap confidence intervals. J Am Stat Assoc 1987;82:171-200.

29. National Institute of Health and Medical Research (INSERM).
Medical causes of death. Paris: INSERM, 1993. In French.

30. Plato, N, Steineck, G. Methodology and utility of a job-exposure matrix. Am J Ind Med 1993;23:491-502.

31. Kromhout H, Heederik D, Dalderup LM, Kromhout D. Performance of two general job-exposure matrices in a study of lung cancer morbidity in the Zutphen Cohort. Am J Epidemiol 1997;136:698-711.

32. Le Moual, N, Orlowski, E, Schenker MB, Avignon M, Brochard P, Kauffmann F. Occupational exposures estimated by means of job-exposure matrices in relation to lung function in the PAARC survey. Occup Environ Med 1995;52:634-43.

33. Bouyer $J$, Hemon D. Studying the performance of a jobexposure matrix. Int J Epidemiol 1993;22:S65-\$71.

Received for publication: 18 February 1999 